\title{
Resistencia de juntas secas conjugadas de puentes de dovelas prefabricadas de hormigón: propuesta para el Eurocódigo 2
}

\section{Shear strength of match cast dry joints of precast concrete segmental bridges: proposal for Eurocode 2}

\author{
$\underline{\text { J. Turmo }}^{(*)}$, G. Ramos $(* *)$ y A. C. Aparicio(**)
}

Recepción/Received: 22-IV-05

Aceptación/Accepted: 04-X-05

\section{RESUMEN}

Este trabajo presenta un estudio sobre el comportamiento de puentes de dovelas de hormigón con llaves de cortante, centrado en el comportamiento a cortante de las juntas secas conjugadas en Estado Límite Último. Se ha realizado una exhaustiva recopilación de la dispar formulación existente para evaluar la resistencia a cortante de las juntas. Se ha realizado, asimismo, una investigación bibliográfica de los resultados experimentales disponibles sobre este particular en la literatura. Los resultados recogidos en la bibliografía han sido comparados con la variada formulación existente para predecir la resistencia última de las juntas. La fórmula que mejor predice la resistencia ha sido identificada. Ésta ha sido adaptada al formato de seguridad presente en el Eurocódigo 2.

Palabras clave: puentes de dovelas, juntas conjugadas, resistencia a cortante, llaves de cortante, hormigón de alta resistencia.

\section{SUMMARY}

This paper discusses a study on the performance of concrete segmental bridges with shear keys, focusing on the shear behaviour of castellated dry joints under ultimate limit state conditions. The widely varying formulation used to evaluate joint shear strength were compiled, along with the experimental results published in the literature on the subject. The various approaches were evaluated by comparing their predictions of ultimate joint strength to published empirical findings. The formula giving the best prediction was adapted to the safety factor provisions set out in Eurocode 2.

Keywords: segmental bridges, match cast joints, shear strength, shear keys, high strength concrete.

\section{INTRODUCCIÓN}

En la tecnología actual, la unión entre dovelas prefabricadas de puentes de hormigón se realiza normalmente a través de juntas secas con llaves múltiples conjugadas. Siempre que es posible se evita la disposición de resina

\section{INTRODUCTION}

In present practice, precast concrete bridge segments are normally joined by means of dry joints with multiple match cast shear keys. The use of epoxy resin in joints is avoided whenever possible to save waiting for the

(*) ETS de Ingenieros de Caminos, Canales y Puertos, Universidad de Castilla-La Mancha, C. Real (España).

(**) Dpto. de Ingeniería de la Construcción, Universidad Politécnica de Cataluña, Barcelona (España). 
epoxi en el plano de la unión. Esto permite ahorro de tiempo, ya que no es necesario esperar a que la resina polimerice, e independiza la construcción de la climatología. El procedimiento constructivo clásico de empleo de juntas secas sin resina es el de los puentes construidos vano a vano con pretensado exterior $(1,2)$.

Para evaluar la resistencia a cortante de las juntas secas sin resina con llaves de cortante, la teoría universalmente aceptada propone que el cortante es transmitido a través de la junta mediante dos mecanismos cualitativa y cuantitativamente diferentes $(3,4,5)$. El primero representa la fuerza de rozamiento que surge cuando dos superficies planas y comprimidas intentan deslizar la una contra la otra y que es proporcional a las compresiones actuantes, llamándose este factor de proporcionalidad, coeficiente de rozamiento $\mu_{1}$. El segundo recoge el efecto del apoyo de las llaves conjugadas. Estas llaves permiten la transferencia de cortante cuando están en contacto una con otra, comportándose como unas pequeñas ménsulas de hormigón en masa (sus pequeñas dimensiones impiden que éstas estén convenientemente armadas). La resistencia a cortante de estas llaves por unidad de área es lo que se llama cohesión c. Si sobre estas llaves están actuando tensiones de compresión $\sigma_{n}$, la ménsula de hormigón en masa será ahora una ménsula pretensada, incrementándose la tensión tangencial última de manera proporcional a la compresión. A este factor de proporcionalidad, siguiendo la terminología de Fouré (5), lo llamaremos rozamiento interno $\mu_{2}$.

Aunque los mecanismos de transmisión de cortante a través de las juntas secas son cualitativamente bien conocidos, los autores no coinciden en su cuantificación (3, 4, 5). La aplicación de la formulación propuesta por los autores conduce a valores del cortante último respuesta de las juntas secas muy dispares (resultados que varían en proporción de 2 a 1) (6). Algunas de estas fórmulas provienen de trabajos teóricos (7). Otras son fruto de trabajos experimentales en los que se ha estudiado profusamente el comportamiento a nivel probeta de una única llave, asumiendo que la resistencia de una junta con varias llaves es la suma algebraica de las resistencias de cada una de las llaves $(8,9)$. El resumen de los distintos valores propuestos para los términos $c, \mu_{1}$ y $\mu_{2}$, encontrados en la literatura pueden consultarse en la Tabla 1 , donde $f_{c}$ corresponde a la resistencia característica del hormigón y $f_{t}$ representa su resistencia a tracción.

A pesar de que la investigación teórica $(3,4,5)$ y experimental $(5,8,10,11,12)$ es abundante, la normativa europea referente a estructuras de hormigón con pretensado exterior (13) no recoge ninguna fórmula para evaluar la resistencia de estas juntas. En este trabajo se presenta una evaluación razonada de la distinta formulación existente en la bibliografía y se propone una fórmula para resin to polymerize, particularly where weather conditions are adverse. The use of resin-free dry joints is a construction procedure typical of externally pre-stressed bridges erected span-by-span $(1,2)$.

According to the universally accepted theory on shear strength assessment in dry joints with shear keys, shear stress is transmitted across the joint by two qualitatively and quantitatively different mechanisms $(3,4,5)$. The former, which refers to the friction stress arising when two flat, compressed surfaces try to move relative to one another, is proportional to the compression forces involved; this proportionality factor is known as friction coefficient $\mu_{1}$. The latter addresses the effect of the castellated shear keys. When their two opposing elements are in contact, these keys transmit shear stress, behaving like tiny plain concrete cantilevers (their small dimensions precluding reinforcement). The shear strength of these keys by unit of area is known as cohesion, c. If keys are subjected to compressive stress, $\sigma_{n}$ the plain concrete cantilever becomes a pre-stressed cantilever, while the ultimate tangential stress increases in proportion to the compressive loading. Borrowing from Fouré's notation (5), in the present paper this proportionality factor is called internal friction, $\mu_{2}$.

Although the mechanisms for shear stress transmission across dry joints are well understood from the qualitative standpoint, their quantification differs from one author to another $(3,4,5)$. Applying the various models proposed yields very divergent ultimate shear capacity values for dry joints (with results varying by up to 100\%) (6). Some of these models are the result of theoretical studies (7) and others the outcome of experimental work. In the latter context, the behaviour of specimens with a single key has been widely studied, under the assumption that the strength of a joint with several keys is the algebraic sum of their respective strengths $(8,9)$. A summary of the different values proposed in the literature for terms $c, \mu_{1}$ and $\mu_{2}$ is given in Table 1 , where $f_{c}$ is the characteristic compressive strength, and $f_{t}$ the tensile strength of concrete.

Despite the wealth of theoretical $(3,4,5)$ and experimental $(5,8,10,11,12)$ research, no formula for assessing the strength of these joints is advanced in European codes on externally pre-stressed concrete structures (13). This article introduces a rationale for evaluating the different models found in the literature and proposes a formula for adapting the optimum model to European 
Tabla 1 / Table 1

Fórmulas existentes para predecir los valores de las componentes de la resistencia de las juntas

Formulas to predict the values of joint strength components

\begin{tabular}{|lccc|}
\hline & $\mu_{\mathbf{1}}$ & $\mu_{\mathbf{2}}$ & $\mathbf{c}$ (MPa) \\
\hline Buyukozturk & $*$ & 1.36 & $0.647 \cdot \sqrt{f_{c}}$ \\
\hline Breen & 0.60 & $0.205 \cdot \sqrt{f_{c}}$ & $0.996 \cdot \sqrt{f_{c}}$ \\
\hline Fouré & $*$ & $0.5 \cdot \sqrt{f_{c}^{1 / 3}}$ & $0.5 \cdot f_{t}$ \\
\hline ATEP & 0.60 & 1.14 & $1.8 \cdot \sqrt{f_{c}}$ \\
\hline
\end{tabular}

$*$ No definido explicitamente / Not explicitly defined.

adaptar la formulación óptima a la normativa europea. Asimismo, se propone la fórmula a utilizar en el caso de emplear hormigones de alta resistencia.

\section{VALORACIÓN DE LA FORMULACIÓN EXISTENTE PARA EVALUAR LA RESISTENCIA DE LAS JUNTAS SECAS SIN EPOXI}

En la Tabla 2 se resumen los resultados de distintos ensayos encontrados en la literatura. En concreto, se recogen los ensayos descritos por Backhoum (8), realizados sobre juntas provistas de una única llave, el realizado por Koseki (12) sobre un panel provisto de múltiples llaves, los ensayos realizados por Polo y Llopart sobre paneles con llaves múltiples $(10,11)$ y los ensayos descritos por Fouré $(5)$ sobre elementos con sección cajón. En todos estos ensayos, el colapso estructural se produce por la rotura de una junta, quedando reflejado en la Tabla el cortante último en la misma bajo carga máxima $\mathrm{V}_{\mathrm{U}, \mathrm{T}}$. building codes. It also proposes a model to be used with high strength concrete.

\section{EVALUATION OF EXISTING MODELS FOR DETERMINING DRY JOINT STRENGTH}

Table 2 contains a summary of the different tests found in the literature. Specifically, it lists the trials conducted by Backhoum (8) on joints with a single key, Koseki (12) on a multiple key panel, Polo and Llopart on multiple key panels $(10,11)$ and Fouré $(5)$ on box girders. In all these tests, structural collapse was caused by failure of a single joint at the ultimate shear stress specified on the Table, reached under maximum loading $V_{U, T}$.

Tabla 2 / Table 2

Evaluación de la formulación existente

Evaluation of existing models

\begin{tabular}{|c|c|c|c|c|c|c|c|c|c|}
\hline \multirow{4}{*}{ Backhoum-100 } & \multirow{3}{*}{\begin{tabular}{l|} 
Test \\
$\mathrm{V}_{\mathrm{U}, \mathrm{T}}$ \\
$\mathrm{MN}$ \\
\end{tabular}} & \multicolumn{2}{|c|}{ Buyukozturk } & \multicolumn{2}{|c|}{ Fouré } & \multicolumn{2}{|c|}{ AASHTO } & \multicolumn{2}{|c|}{ ATEP } \\
\hline & & $\mathbf{V}_{\mathrm{U}, \mathbf{P}}$ & $\mathbf{V}_{U, T} / V_{U, P}$ & $\mathbf{v}_{\mathrm{U}, \mathbf{P}}$ & $\mathbf{V}_{\mathrm{U}, \mathrm{T}} / \mathbf{V}_{\mathrm{U}, \mathrm{P}}$ & $\mathbf{V}_{\mathrm{U}, \mathrm{P}}$ & $\mathbf{V}_{U, T} / V_{U, P}$ & $\mathbf{v}_{\mathbf{U}, \mathbf{P}}$ & $\mathbf{V}_{U, T} / V_{U, P}$ \\
\hline & & \multicolumn{2}{|c|}{ MN } & \multicolumn{2}{|c|}{ MN } & \multicolumn{2}{|c|}{ MN } & \multicolumn{2}{|c|}{ MN } \\
\hline & 0.064 & 0.064 & 0.999 & 0.025 & 2.595 & 0.062 & 1.032 & 0.084 & 0.764 \\
\hline Backhoum-300 & 0.082 & 0.084 & 0.981 & 0.045 & 1.814 & 0.078 & 1.058 & 0.109 & 0.757 \\
\hline Backhoum-500 & 0.112 & 0.107 & 1.045 & 0.069 & 1.632 & 0.098 & 1.140 & 0.138 & 0.812 \\
\hline Koseki & 0.213 & 0.226 & 0.944 & 0.143 & 1.491 & 0.207 & 1.030 & 0.287 & 0.743 \\
\hline Fouré-OH2 & 0.795 & 0.628 & 1.267 & 0.664 & 1.198 & 0.699 & 1.137 & 0.473 & 1.682 \\
\hline Fouré-OH3 & 0.413 & 0.550 & 0.751 & 0.570 & 0.724 & 0.600 & 0.688 & 0.360 & 1.147 \\
\hline Fouré-OH3BIS & 0.505 & 0.550 & 0.918 & 0.591 & 0.855 & 0.600 & 0.842 & 0.360 & 1.403 \\
\hline Polo-PC-R-2 & 0.285 & 0.272 & 1.049 & 0.272 & 1.049 & 0.296 & 0.962 & 0.296 & 0.962 \\
\hline Polo-PC-C-2 & 0.538 & 0.365 & 1.472 & 0.078 & 6.862 & 0.354 & 1.518 & 0.482 & 1.116 \\
\hline Polo-PC-JC & 0.385 & 0.462 & 0.833 & 0.298 & 1.290 & 0.400 & 0.963 & 0.593 & 0.649 \\
\hline Llopart-SFRC-R-2 & 0.271 & 0.273 & 0.993 & 0.273 & 0.993 & 0.298 & 0.911 & 0.298 & 0.911 \\
\hline Llopart-SFRC-JC & 0.357 & 0.443 & 0.806 & 0.280 & 1.276 & 0.382 & 0.935 & 0.569 & 0.628 \\
\hline Llopart-SFRC-JA & 0.173 & 0.369 & 0.469 & 0.267 & 0.647 & 0.236 & 0.733 & 0.468 & 0.369 \\
\hline Media / Mean & & & 0.96 & & 1.73 & & 1.00 & & 0.92 \\
\hline $\begin{array}{l}\text { Desviación estándar } \\
\text { Standard deviation }\end{array}$ & & & 0.058 & & 2.650 & & 0.043 & & 0.122 \\
\hline
\end{tabular}


Además, para las condiciones últimas medidas en los ensayos (valores de los axiles, momentos flectores concomitantes...) en la Tabla 2 se presenta el cortante último respuesta $\mathrm{V}_{\mathrm{U}, \mathrm{P}}$ predicho por la formulación propuesta por Buyukozturk (4), Fouré (5), por la normativa AASHTO (14), derivada de la formulación del profesor Breen (3), y por las recomendaciones españolas (15). Con objeto de que al evaluar este cortante último respuesta se obtuvieran valores comparables, se han calculado los valores característicos de la respuesta.

Bajo la denominación de Backhoum-100, se recoge en la Tabla 2 el valor del cortante último respuesta medio de la serie de ensayos realizados sobre cuatro probetas con una tensión de confinamiento de 100 psi $\left(\sigma_{n m}=0,6895\right.$ $\mathrm{MPa})$. De manera análoga se calculan los valores correspondientes a Backhoum-300 (3 ensayos) y Backhoum500 (5 ensayos). El resto de los ensayos tienen la nomenclatura que los identifica en la bibliografía citada $(5,10,11,12)$.

Las fórmulas existentes para evaluar la resistencia de las juntas secas son todas conceptualmente muy similares, pero muy diferentes en su aplicación. Esto dificulta enormemente su comparación (16). En cualquier caso, del estudio de los resultados de la Tabla 2, se puede extraer como conclusión general que es la formulación de la AASHTO la que mejor aproxima los resultados para la serie de ensayos analizados, tanto en media como en varianza. Conceptualmente, esta formulación es muy acertada. En primer lugar, separa el cortante que es capaz de transmitirse por el área de las llaves $A_{k}$ y el cortante que es capaz de transmitirse por la superficie lisa entre llaves $A_{s m}$. Siendo conocido (medido) el rozamiento entre las superficies de hormigón $\left(\mu_{1}\right)$, el problema se centra en determinar la cohesión c y el rozamiento interno $\mu_{2}$. El profesor Breen hace depender estos dos términos de la resistencia a tracción del hormigón, imponiendo que cuando las tensiones tangenciales en el seno de la llave hacen que se alcance la tensión principal de tracción, las llaves rompen. Breen no considera que la rotura pueda deberse a solicitaciones de flexión local de la llave. La fórmula propuesta por la AASHTO, sin seguridad, es la siguiente:

$$
V_{u}=A_{k} \cdot \sqrt{f_{c}^{\prime}} \cdot\left(0.2048 \cdot \sigma_{n}+0.9961\right)+0.6 \cdot A_{s m} \cdot \sigma_{n}
$$

donde: $A_{k}$ es el área de todas las llaves en el plano de rotura

$f_{c}^{\prime}$ es la resistencia característica del hormigón a compresión en $\mathrm{MPa}$

$\sigma_{n}$ es la tensión de compresión media en el plano de la junta en $\mathrm{MPa}$

$A_{s m}$ es el área de contacto entre superficies lisas en el plano de rotura
Table 2 also shows the ultimate shear values, $V_{U, P,}$ for the ultimate conditions measured in the tests (axial stress values, concomitant bending moments...), as predicted by Buyukozturk (4), Fouré (5), AASHTO specifications (14) [derived from Prof. Breen's (3) model] and Spanish recommendations (15). The respective characteristic response values were computed to ensure that the ultimate shear capacity values obtained would be comparable.

The mean ultimate shear capacity of a series of tests conducted on four specimens with a confining stress of $100 \mathrm{psi}\left(\sigma_{\mathrm{nm}}=0.6895 \mathrm{MPa}\right)$ is given in Table 2 under the heading Backhoum-100. The values for Backhoum-300 (3 tests) and Backhoum-500 (5 tests) were similarly computed. All other tests are denominated in the Table as identified in the literature cited $(5,10,11,12)$.

The existing formulas for finding dry joint strength are conceptually very similar, although their application varies. This renders their comparison particularly difficult (16). It may nonetheless be generally inferred from the results in Table 2 that the AASHTO model is the one that best estimates the results of the tests analyzed, in terms of both mean and standard deviation. This model is very sound, conceptually speaking. Firstly, it separates the shear stress that can be transmitted across the area occupied by the keys, $A_{k}$ from the stress transmitted across the smooth area in between keys, $A_{s m}$. Since the friction between the concrete surfaces $\left(\mu_{1}\right)$ can be measured, the problem consists in finding cohesion $c$ and internal friction $\mu_{2}$. Prof. Breen makes these two terms contingent upon concrete tensile strength, establishing the condition that keys fail when the principal tensile stress is reached due to tangential stresses within the key. Prof. Breen does not regard failure to be due to local flexural stress on the key. The formula proposed by AASHTO, prior to application of the safety factor, is as follows: where: $A_{k}$ is the area of all the keys along the plane of fracture, $f_{C}^{\prime}$ is characteristic concrete compressive strength, in $\mathrm{MPa}$, $\sigma_{n}$ is the mean compressive stress along the plane of the joint, in MPa, $A_{s m}$ is the contact area between smooth surfaces along the plane of fracture. 
Buyukozturk aproxima relativamente bien el conjunto de resultados, sobre todo teniendo en cuenta que la formulación por él propuesta no tiene más justificación teórica que la extrapolación de unos resultados experimentales obtenidos de unas probetas a todo tipo de geometrías y hormigones. No separa el cortante que es capaz de transmitirse por las llaves y el cortante que es capaz de transmitirse por la superficie lisa entre llaves, englobándolo todo en el coeficiente de rozamiento $\mu_{2}$, por lo que una alteración entre la proporción $A_{k}$ y $A_{s m}$ podría hacer variar estos resultados. La predicción del panel SFRC-JA queda excesivamente del lado inseguro.

La formulación de Fouré es conceptualmente interesante porque hace depender la magnitud del coeficiente de rozamiento interno $\mu_{2}$ de la resistencia del hormigón y además separa el cortante que es susceptible de transmitirse por $A_{k} y$ por $A_{s m}$. Sin embargo, su formulación da valores para el término de la cohesión c muy bajos, lo que, para los niveles de tensiones normales de los ensayos, da lugar a predicciones excesivamente conservadoras. Fouré es el único autor que considera la contribución de las llaves por debajo de la fibra neutra en la transmisión de cortante. Aunque los ensayos $(10,11)$ parecen confirmar que las llaves en contacto por debajo de la fibra neutra son capaces de transmitir cortante, parece razonable no tenerlas en cuenta a la hora de evaluar la resistencia de la junta. En primer lugar, no es sencillo determinar a priori qué llaves quedarán en contacto por debajo de la fibra neutra. Además, la inexistencia de tensiones normales de compresión hace que estas llaves contribuyan en menor grado a la transmisión de tensiones tangenciales y que su resistencia sea menor.

En cuanto a la formulación propuesta por la ATEP hay que decir que no separa el cortante que es capaz de transmitirse por las llaves y el cortante que es capaz de transmitirse por la superficie lisa entre llaves, englobándolo todo en el coeficiente de rozamiento $\mu_{2}$. Éste, además, no depende de la resistencia del hormigón, lo que conceptualmente no tiene lógica. En los ensayos de paneles, la resistencia es sistemáticamente supervalorada.

\section{SUGERENCIAS PARA LA FORMULACIÓN A ADOPTAR EN ESPAÑA Y EN EUROPA}

Habida cuenta de que las actuales recomendaciones españolas supervaloran la contribución de las junta y de que la normativa europea no recoge ningún tipo de fórmula para evaluar la resistencia de las juntas secas conjugadas, parecería razonable que tanto las recomendaciones españolas como los Eurocódigos incluyeran la formulación de la AASHTO aplicando el formato de seguridad característico de los mismos.
Buyukozturk's model estimates the results relatively well on the whole, especially considering that its only theoretical understructure is the extrapolation of certain experimental results obtained from specimens with all types of geometries made with different concrete grades. It does not separate the shear stress that can be transmitted across the keys from the stress flowing across the smooth surface between keys, but rather includes all shear stress in friction coefficient $\mu_{2} ;$ as a result, any alteration in the $A_{k} / A_{s m}$ ratio may lead to variations in the results. The prediction for panel SFRC-JA is too far into the unsafe side.

The Fouré model is conceptually attractive because in it the magnitude of the internal friction coefficient $\mu_{2}$ depends on concrete strength, and it separates the shear stress liable to be transmitted across $A_{k}$ from the stress flowing across $A_{s m}$. Nonetheless, the model gives very low values for the cohesion term, $c$, which results in overly conservative predictions for normal stress test levels. Fouré is the only author to address the contribution of the keys located beneath the neutral axis. Although tests $(10,11)$ seem to confirm that even when keys are in contact underneath the neutral axis they can transmit shear stress, their impact can be reasonably disregarded when evaluating joint strength. Firstly, it is not easy to determine, a priori, which keys will be in contact below the neutral axis. Moreover, in the absence of normal compressive stress these keys exhibit lower strength and their relative contribution to tangential stress transmission is smaller.

The model proposed by ATEP does not separate the shear stress that can be transmitted across the keys from the stress flowing across the smooth surface between keys, but includes all shear stress in friction coefficient $\mu_{2}$. Nor does the coefficient depend on concrete strength, a conceptually illogical assumption. Moreover, strength is systematically overestimated in panel tests.

\section{SUGGESTED APPROACH FOR ADOPTION IN SPAIN AND EUROPE}

Inasmuch as the recommendations presently in place in Spain overestimate joint strength and European codes contain no model to assess match cast castellated dry joint shear strength, it would appear to be reasonable for both the Spanish recommendations and the Eurocodes to adopt the AASHTO model, subject to adaptation to the respective safety factor provisions. 
Como la fórmula deducida por Roberts y Breen de manera teórica (Ecuación [1]) hace depender la resistencia de las juntas del la resistencia a tracción del hormigón propuesta por la normativa americana (Ecuación [2])
Since in the theoretical formula deduced by Roberts and Breen (Equation [1]), joint strength depends on the concrete tensile strength proposed by the American codes (Equation [2])

$$
f_{t}=7.5 \cdot \sqrt{f_{c}^{\prime}}
$$

y como parece más razonable hacer depender la fórmula europea de la resistencia característica inferior a tracción $f_{c t, k, 0,05}$ del hormigón propuesta por el EC2 (Ecuación [3]), and since it appears to be more reasonable for the European formula to depend on the characteristic lower bound tensile strength $f_{c t, k, 0.05}$ proposed in EC2 (Equation [3]),

$$
f_{c t, k, 0.05}=0.21 \sqrt[3]{f_{c k}^{2}} \text { sif } f_{c k} \leq 50 \mathrm{MPa}
$$

la fórmula de Breen y Roberts puede ser reescrita en la forma propuesta en la Ecuación [4]: the Breen and Roberts formula can be re-written as shown in Equation [4]:

$$
V_{u}=\frac{1}{\gamma_{c}} \cdot\left(A_{k} \cdot \frac{\sqrt[3]{f_{c k}^{2}}}{100} \cdot\left(7 \cdot \sigma_{n}+33\right)+0,6 \cdot A_{s m} \cdot \sigma_{n}\right) \begin{aligned}
& \text { si } f_{c k} \leq 50 M P a \\
& \text { if }
\end{aligned}
$$

en la que, además, se incluye el término $\gamma_{c}$, coeficiente de minoración de la propiedades del material $\left(\gamma_{c}=1,5\right.$ para acciones transitorias o $\gamma_{c}=1,3$ para acciones accidentales) a considerar en los Estados Límites Últimos.

Hay que destacar que la fórmula propuesta por el EC2 de la resistencia característica inferior a tracción $f_{c t, k}$ es válida para hormigones de hasta $50 \mathrm{MPa}$ de resistencia característica a compresión. De emplear hormigones de alta resistencia, la fórmula 4 debería ser modificada, de modo que se derivara de la fórmula propuesta para la resistencia tracción del hormigón de alta resistencia (Ecuación [5]).
In this expression the term $\gamma_{c}$ is the safety coefficient for material properties ( $\gamma_{c}=1.5$ for temporary loads and $\gamma_{c}=1.3$ for accidental loads) to be used when working with ultimate limit states.

The formula proposed by EC2 for the characteristic lower bound concrete tensile strength $f_{c t, k}$ is valid for concretes with a characteristic compressive strength of up to 50 $\mathrm{MPa}$. Where high-strength concrete is used, a formula analogous to expression 4 must be derived from the formula proposed in the above code for tensile strength in high-strength concrete (Equation [5]):

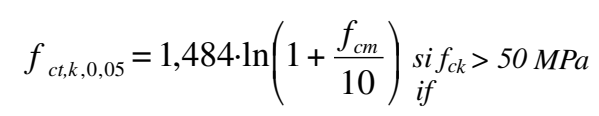

Que depende de la resistencia media a compresión del hormigón $f_{c m}$. Así la formulación a emplear para evaluar la resistencia de las juntas secas para hormigones de alta resistencia $\left(f_{c k}>50 \mathrm{MPa}\right.$ ) sería (Ecuación [6]):
This, in turn, depends on mean concrete compressive strength $f_{c m}$. Therefore, the formula to be used to assess dry joint strength in high-strength concrete ( $f_{c k}>$ $50 \mathrm{MPa}$ ) would be (Equation [6]):

$$
V_{u}=\frac{1}{\gamma_{c}} \cdot\left(A_{k} \cdot \frac{\ln \left(1+\frac{f_{c m}}{10}\right)}{100} \cdot\left(49 \cdot \sigma_{n}+233\right)+0,6 \cdot A_{s m} \cdot \sigma_{n}\right) \begin{aligned}
& \text { si } f_{c k}>50 \mathrm{MPa} \\
& \text { if }
\end{aligned}
$$

Del mismo modo, el coeficiente de rozamiento propuesto es el especificado en la normativa AASHTO. Cuando por las características de la dosificación empleada o por las características de la construcción sea factible que el rozamiento entre hormigones no alcance este valor, el coeficiente de rozamiento $\mu_{1}$ deberá ser convenientemente disminuido.
Similarly, the friction coefficient proposed is as specified in the AASHTO guide. When for reasons of mix dosage or construction conditions inter-concrete friction is unlikely to reach this value, friction coefficient $\mu_{1}$ should be lowered accordingly. 


\section{CONCLUSIONES}

La existencia de llaves conjugadas aumenta la resistencia de la junta. La formulación que mejor predice los resultados de los ensayos es la formulación del profesor Breen. Hay que destacar que la misma fue deducida teóricamente. La AASHTO propone la fórmula de Breen (Ecuación [1]), aplicando un coeficiente de seguridad en la respuesta $\phi_{\mathrm{j}}=0,75$.

Esta fórmula separa el cortante que la junta es capaz de transmitir por las llaves $A_{k}$ y el cortante que es capaz de transmitirse por la superficie lisa entre llaves $A_{s m}$. El coeficiente de rozamiento entre las superficies de hormigón $\mu_{1}$ toma un valor de 0,6 muy similar al coeficiente de rozamiento medido en los ensayos. Los valores de la cohesión c y el rozamiento interno $\mu_{2}$ se hacen depender de la resistencia a tracción del hormigón, imponiendo que cuando las tensiones tangenciales en el seno de la llave hacen que se alcance la tensión principal de tracción, las llaves rompen.

La normativa europea no recoge ningún tipo de fórmula para evaluar la resistencia de las juntas secas conjugadas. Parecería razonable que los eurocódigos incluyeran la formulación de la AASHTO, aplicando el formato de seguridad característico de los mismos. Las actuales recomendaciones españolas supervaloran la contribución de las juntas. La fórmula propuesta para las recomendaciones españolas, directamente derivada de la fórmula de Breen y Roberts, aplicando el formato EC2, queda definida por la Ecuación [4].

Por otro lado, es necesario apuntar que el rango de validez de la fórmula que evalúa la resistencia a tracción del hormigón no es ilimitado. Es sabido que en hormigones con alta resistencia a compresión $\left(f_{c k}>50 \mathrm{MPa}\right)$, la resistencia a la tracción no es comparativamente tan alta. Así pues, para estos tipos de hormigones la fórmula a aplicar sería la Ecuación [6].

Cuando por las características de la dosificación empleada o por las características de la construcción sea factible que el rozamiento entre hormigones no alcance este valor, el coeficiente de rozamiento $\mu_{1}$ deberá ser convenientemente disminuido.

\section{AGRADECIMIENTOS}

Al Ministerio de Ciencia y Tecnología español, por financiar parcialmente la investigación desde el proyecto MAT200200849. Al Ministerio de Fomento español, por la financiación parcial de la investigación a través del proyecto "Estudio teórico experimental de la transferencia de cortante en vigas de dovelas de hormigón reforzado con fibras, con

\section{CONCLUSIONS}

Match cast shear keys increase joint strength. The formula that best predicts test results is the one developed on purely theoretical grounds by Prof. Breen and Roberts. AASHTO proposes a modified version of Prof. Breen's formula (Equation [1]) in which a safety coefficient, $\phi_{j}=0,75$, is applied to the result.

This formula separates the shear stress that can be transmitted across keys, $A_{k}$, from the stress flowing across the smooth surface between keys, $A_{s m}$, while the value adopted for the inter-surface friction coefficient is 0.6 , i.e., very similar to the empirical value. Moreover, cohesion $c$ and internal friction $\mu_{2}$ depend upon concrete tensile strength and are subject to the condition that the keys fail when the principal tensile stress is reached due to tangential stresses within the key.

European codes contain no model for assessing match cast castellated dry joint strength. It would appear to be reasonable for the Eurocodes to include the AASHTO model, adapted to European safety factor provisions. Spanish recommendations presently in place overestimate joint strength. The model proposed for Spanish recommendations, derived by applying EC2 safety factor provisions to the Breen and Roberts formula, is defined by Equation [4].

The validity of the formula for assessing concrete tensile strength is not unlimited in range. Concretes with a high compressive strength $\left(f_{c k}>50 \mathrm{MPa}\right)$ are known to have comparatively lower tensile strengths. Consequently, the formula to be applied when such concretes are involved would be Equation [6].

When for reasons of mix dosage or construction conditions inter-concrete panel friction may be unlikely to reach that value, friction coefficient $\mu_{1}$ must be lowered accordingly.

\section{ACKNOWLEDGEMENTS}

The present study was partially funded by the Spanish Ministry of Science and Technology under project MAT2002-00849 and the Spanish Ministry of Internal Development under the project "Theoretical experimental study of shear stress transmission across dry joints in externally pre-stressed fibre-reinforced concrete segmental 
pretensado exterior y junta seca". Al Ministerio de Educación y Cultura español, por la beca de Formación de Profesorado Universitario que recibió uno de los autores y que disfrutó desde 2000 hasta 2003. girders". One of the authors benefited from a Spanish Ministry of Education and Culture university teacher training grant between 2000 and 2003.

\section{BIBLIOGRAFÍA/BIBLIOGRAPHY}

(1) Muller, J.: "Construction of the Long Key Bridge", Journal of the Prestressed Concrete Institute, november-december (1980), pp. 97-111.

(2) Shafer, G.: "Bangkok Blockbuster", Civil Engineering Magazine. ASCE, vol. 69, n. 1, january (1999), pp. 32-35.

(3) Ramírez, G., MacGregor, R., Kreger, M. E., Roberts-Wollmann, C., Breen, J.: "Shear Strength of Segmental Structures", Proceedings of the Workshop AFPC External Prestressing in Structures. Saint-Rémy-lès-Chevreuse, june (1993), pp. 287-296.

(4) Buyukozturk, O., Backhoum, M. M., Beattie, S. M.: "Shear Behavior of Joints in Precast Concrete Segmental Bridges", ASCE Journal of Structural Engineering, december (1990), pp. 3380-3401.

(5) Foure, B., Bouafia, Y., Soubret, R., Thomas, P.: "Shear Test on Keyed Joints between Precast Segments", Proceedings of the Workshop AFPC External Prestressing in Structures, Saint-Rémy-lès-Chevreuse, june (1993), pp. 297-319.

(6) Aparicio, A. C., Ramos, G., Casas, J. R.: "Testing of externally prestressed concrete beams", Engineering Structures, n. 24 (2001), pp. 73-84.

(7) Roberts, C. L.: "Measurement Based Revisions for Segmental Bridge Design and Construction Criteria", PhD Dissertation, The University of Texas at Austin, december (1993).

(8) Bakhoum, M. M.: "Shear Behaviour and Design of Joints in Precast Concrete Segmental Bridges", PhD Dissertation, Massachussetts Institute of Technology, 1991.

(9) Beattie, S. M.: "Behavioral Improvements in Segmental Concrete Bridge Joints through the Use of Steel Fibers", MS Dissertation, Massachussetts Institute of Technology, 1989.

(10) Polo, T.: "Experimental Study on Shear Strength of Precast Concrete Segmental Bridges", MSc Thesis, Universitat Politècnica de Catalunya, Barcelona, España, 2001 (in Spanish).

(11) Llopart, S.: "Experimental Study on Shear Strength of Dry Joints of SFRC Segmental Bridges", MSC Thesis, Universitat Politècnica de Catalunya, Barcelona, España, 2001 (in Spanish).

(12) Koseki, K., Breen, J.: "Exploratory Study of Shear Strength of Joints for Precast Segmental Bridges", Texas State Department of Highways and Public Transportation, september (1983).

(13) EC 2 1-5 UNE-ENV 1992-1-5: "General Guidelines for Unbonded or External Prestressed Structures", AENOR, april (1996).

(14) AASHTO: "Guide Specifications for Design and Construction of Segmental Concrete Bridges", Washington, 1998.

(15) ATEP: "Proyecto y construcción de puentes y estructuras con pretensado exterior", Madrid, septiembre (1996).

(16) Turmo, J.: "Flexure and Shear Behaviour of Segmental Concrete Bridges with External Prestressing and Dry Joints" (in Spanish). ETSICCP de Barcelona. Dept. Ing. de la Construcción, julio (2003). 